\title{
Embryo and stem cell research in the United States: history and politics
}

\author{
DC Wertz \\ University of Massachusetts Medical School, Waltham, MA, USA
}

\begin{abstract}
Stem cell research in the United States is inevitably connected with the politics of abortion. Since 1973, when the Supreme Court Roe v Wade decision legalized abortion, the US government has refused to fund embryo research, including IVF, because Congress feared this would encourage women to have abortions. IVF and infertility research have taken place in an unregulated private sector. Bush's decision allowing federal funds for research on stem cells
\end{abstract}

derived before 9 August 2001 may be the first use of federal finds, though the overall ban on embryo research still stands. This paper examines 30 years of US refusal to fund embryo research, cultural background, religious beliefs as these affect stem cell research, as well as the ethical issues related to creating blastocysts to specifically derive stem cells, and therapeutic cloning.

Gene Therapy (2002) 9, 674-678. DOI: 10.1038/sj/gt/3301744

Keywords: stem cells; ethics; embryo research; religious views

\section{Introduction}

In the United states, the history of embryo research (which now includes stem cells) has been closely entwined with the abortion debate for almost 30 years. Starting in 1973, shortly after the Supreme Court's Roe v. Wade decision, which legalized abortions, the US government banned use of federal funds for research on embryos, fetuses, and embryonic or fetal tissue, while permitting largely unregulated research in the private sector. ${ }^{1}$ The bans have driven most infertility research and treatment, including IVF, into the private sector.

\section{Thirty years without federal funds}

The following is a brief outline of the ups and downs of embryo research.

\section{3}

Supreme Court decision in Roe v. Wade rules that decisions about abortion are private, between a woman and her doctor. States may not forbid abortion in first two trimesters. This decision sparks a large, politically active anti-abortion movement that opposes research on embryos. Members of Congress become concerned about research exploitation of embryos and fetuses that will be aborted. Department of Health, Education, and Welfare (DHEW, later Department of Health and Human Services, DHHS) places moratorium on research on living embryos.

\section{4}

Congress applies its own temporary moratorium on federally funded clinical research on embryos and embryonic tissue, including research on IVF, infertility, and prenatal diagnosis, until national guidelines can be established. A de facto moratorium continues until the present. Basic, nontherapeutic, research using embryonic cells continues, out of public view. Congress establishes National Commission (NC) for the Protection of Human Subjects of Biomedical and Behavioral Research. NC's first mandate is ethical guidelines for fetal and embryo research. NC specifies that societal protection of human subjects should be extended to embryos and fetuses, even in the context of abortion, and recommends establishment of a national Ethics Advisory Board (EAB) to review protocols.

\section{July 1975}

Department of Health and Human Services (DHHS) adopts regulations for research on embryos, based on NC recommendations and subject to approval of research protocols by an EAB. DHHS lifts moratorium, but no infertility or therapeutic research is funded. Basic research continues.

May 1979

EAB approves federal funds for a research protocol on IVF and embryo transfer up to 14 days, requires that donors be married. DHHS rejects EAB recommendations.

EAB charter and funding expire, leaving no lawful body that can approve embryo research protocols. EAB is never replaced.
Correspondence: DC Wertz, University of Massachusetts Medical School, Shriver Division, 200 Trapelo Road, Waltham, MA 02452, USA 
October 1987

National Institutes of Health (NIH) receives request for funds for research on Parkinson's disease, using transplants of fetal neural cells into patients' brains.

\section{March 1988}

DHHS withholds approval. Assistant Secretary of Health Windom argues that this research would induce women ambivalent about abortion to have one. NIH establishes Human Fetal Tissue Transplantation Research Panel.

\section{December 1988}

Panel votes 18-3 for funding of embryo and fetal research. The majority argues that use of fetal tissue to treat disease can be separated from the morality of abortion.

\section{November 1989}

DHHS Secretary Sullivan extends moratorium indefinitely, accepting the view of three theologically conservative members of the Panel that research would increase abortions.

\section{0}

Congress attempts to override moratorium but President George Bush vetoes.

\section{October 1992}

Disease advocacy organizations file suit against DHHS Secretary Sullivan to lift ban.

\section{January 1993}

President Clinton, in one of his first acts in office, instructs DHHS Secretary Shalala to lift ban.

\section{February-March 1993}

Ban lifted. NIH publishes guidelines, preparatory to accepting proposals for funding. However, fearful of Congressional opposition, NIH does not fund projects on cancer and infertility, although they passed scientific review.

\section{November 1994}

NIH Human Embryo Research Panel supports research, and a narrow majority says that creation of embryos solely for research will not encourage abortions.Clinton overrides Panel after receiving thousands of outraged comments from public.

\section{5}

Congress bans federal funding for research on embryos, but does not specify whether this applies to cells already derived from an embryo. Ban continues to present day.

\section{0}

In an attempt to compromise, NIH legal department rules that NIH may fund research on stem cells that have already been derived from blastocysts, but may not fund the derivation itself. In other words, federally funded researchers may work with existing cells, but may not use embryos to obtain the cells. Private industry is allowed to do the derivation. NIH invites proposals for funding.

\section{March 2001}

Only two proposals received (one later withdrawn), because of perceived political instability. Peer review is halted pending a decision by President George W Bush.
July 2001

The Jones Institute, an infertility clinic in Norfolk, VA, announces that it has created embryos solely for research, using gamete donors not undergoing IVF. The private sector is not regulated and may create embryos for research.

\section{August 2001}

President George W Bush permits NIH funds for research with an estimated 60 stem cell lines already existing as of that date. Cells must come from embryos left over after IVF. Bush addressed the nation on prime-time TV, setting a historical precedent that made bioethics a national priority.

\section{August 2001}

The New York Times says "Bush waffles". The Boston Globe says "Stem Cell Half-Step". Opponents of embryo and stem cell research are split. Some, including the National Right to Life Committee, praise the decision. Others express muted disappointment. The National Conference of Catholic Bishops expresses dissatisfaction. Scientists question adequacy of existing cell lines. Patient organizations decide to wait for results of preliminary research before pressing for wider limits.

\section{November 2001}

$\mathrm{NIH}$ releases list of 74 acceptable stem cell lines, including some in Australia, Sweden, and India, and once again invites proposals. Many existing lines have been grown in mouse media and may be unsafe for human trials.

\section{November 2001}

Advanced Cell Technology, a private company in Worcester, MA announces that it has cloned human embryos from adult cells, for purposes of deriving stem cells that would be compatible with the donor. Bush urges Congress to outlaw both reproductive and therapeutic cloning.

\section{Research: putting a good face on abortion?}

Basic research on human embryonic tissue continued throughout the moratorium, using federal funds ${ }^{2}$ and without attracting Congressional or public attention. This type of research was unlikely to lead directly to treatment that might engage the media or put an acceptable face on abortion. For example, cultured cell lines from human embryonic kidneys have been used for research on insulin-like growth factor at the National Cancer Institute and the National Institute of Diabetes and Digestive and Kidney Diseases, on follicle-stimulating hormone at the National Institute of Child Health and Human Development, on gene therapy at the National Institute of Neurological Disorders and Stroke, and on gene expression in Wilms' tumor at the Veterans' Administration. Fetal and embryonic tissue has been used by the Environmental Protection Agency to study effects of teratogens on fetal palates, by the University of California at San Francisco to study wound healing, by the University of Miami to study neural transmitters, and by the University of Iowa to study effects of maternal diabetes on lung development, to name just a few institutions. The American Type Culture Collection lists 32 cell lines available commercially from human embryos and 28 from human fetuses. 
Only therapeutically oriented research on embryos was prohibited from receiving federal funds. This includes all infertility research, IVF, genetic therapy on embryos, and research on the time at which HIV enters the embryo or fetus. Congress feared that the possibility of using an aborted fetus in 'therapeutic' research would encourage women to have abortions. Although there is no evidence that women would abort in order to donate fetal tissue, Congress did not want to lend acceptability to abortion. Bush's 9 August 2001 decision did not remove the ongoing moratorium on most human embryo research.

\section{Peculiarities of US culture and religion}

Although many ethical issues arise from stem cell research, including weighty issues of equity and access to treatment, in the US most of the debate has focused on the fate of the pre-embryo, or blastocyst, a cluster of perhaps 120 cells, without even the 'primitive streak' that will become the neural tube, residing in a laboratory container. Abortion opponents, having as yet failed to overturn Roe v. Wade, are fighting the battle on the edge, at the very start of life, even if the pre-embryo will never be implanted in a womb. Many abortion opponents are religious conservatives who believe that embryos have intrinsic value from the moment of conception, whatever their stage of development, wherever they are, and whatever their likely future. It does not matter that the embryo may be one of several hundred thousand left over after IVF and awaiting almost inevitable discard. Believers in intrinsic value regard using an embryo to derive stem cells (thereby destroying the embryo) as tantamount to killing a baby.

Three cultural factors differentiate the US from most European nations with regard to views on the embryo.

First, the US is a church-going nation. In surveys, about $40 \%$ of the population report that they attended a religious service last week, ${ }^{3}$ compared with perhaps 5\% in the UK. Genetics professionals also go to services; in one survey, $36 \%$ said they attended at least once a month. ${ }^{4}$ About $25 \%$ of the general population believes that the Bible is the literal word of God, and another $50 \%$ thinks the Bible is the inspired word of God, though not everything in it is to be taken literally. US politicians must answer to a sizeable segment of voters who are active in conservative religious groups that oppose abortion.

Second, the US has a politically active anti-abortion movement that came to life after Roe $v$ Wade legalized elective abortion. Stem cell research is irretrievably linked with the abortion debate and probably always will be. Meanwhile, it will be politically impossible to separate the stem cell debate from the abortion debate. The usual argument for separating the two debates goes like this: 'A shooting leads to brain death. Is it wrong to use the organs for transplantation because murder is wrong? Will the possibility of organ transplantation increase the murder rate?' Opponents of abortion counter that we can condemn homicide, but abortion is a legally supported murder-machine of gigantic proportions, largely approved by society. Use of embryonic tissue will make women feel less guilty than they should and will further increase society's approval of abortion.

Third, from the seventeenth century, free enterprise has topped the list of American values, ${ }^{5}$ making it diffi- cult to restrain private companies from pursuing their own strategies. Government may be hesitant to incite the wrath of conservatives, but it is also hesitant to impinge on the rights of industry, especially to pursue therapeutic goals. Except for laboratory quality controls, there is no regulation of infertility clinics, which often use profits to conduct their own research.

Religious traditions hold varying views of the embryo's value. Catholic doctrine holds that embryos have intrinsic value. The National Conference of Catholic Bishops is much in the news as the most vocal opponent of stem cell research, even after Bush's decision. However, this conservative body does not represent all American Catholics or all Catholic moral theologians. Polls suggest that the majority of Catholic laypeople approve stem cell research. There is some latitude in moral theology. Although the Pope publicly expressed his disapproval to President Bush before 9 August, he did not speak ex cathedra, which could have made the statement 'infallible' according to Catholic doctrine. A growing number of Catholic moral theologians do not regard very early human embryos as individualized human entities and would allow research before the development of the 'primitive streak' at 14 days, which marks the point at which some cells are destined to become the embryo and others to become the placenta. ${ }^{6}$ This dividing line is widely recognized as having enough symbolic significance to permit research beforehand and prohibit it afterwards. This view is analogous to a centuries-old tradition of 'ensoulment'. According to Thomas Aquinas (following Aristotle and St Augustine), rational souls entered males at 40 days and females at 90 days, thereby establishing personal existence and completing the process of conception. Embryos in the earliest stages had only a 'vegetative' life-force. However, nineteenth-century scientific discoveries about the timing of conception pushed ensoulment into the background. In July 2000 the Pope listed cloning and stem cell research as among 'the evils of Western culture'.

Protestant views vary. Historically, Protestantism supported science, believing that nature was faulty and that God intended us to discover its inner workings and repair it. In the seventeenth century, Boston's Puritan ministers preached the virtues of inoculation for smallpox from the pulpit and even administered it themselves, while the medical establishment held back. ${ }^{7}$ This crusading spirit, originally religious, continues to affect American medical practice and scientific research. Some denominations have expressed support for embryonic stem cell research, including the General Assembly of the Presbyterian Church (http:/ / www.eurekalert.org/pubreleases/2001-06/SaRN-Pvif-1406101.php) and the United Church of Christ. Others have taken the intrinsic value position, including the conservative Missouri Synod Lutheran Church (http://www.islet.org/forum/ messages.19166.htm), the United Methodist Church (http: //www.umc-gbcs.org/bbpr118a.htm) and the Southern Baptist Convention (http://www.sbcannualmeeting.org /sbc99/res7.htm), all three of which oppose embryonic stem cell research and hope that adult stem cells will suffice. In view of their overall support for medicine and technology, some denominations that now oppose may change their minds if embryonic stem cell research succeeds.

Jewish views hold that a fetus outside the mother's 
body does not have the same value as a fetus within her body. Traditionally, a fetus was 'water' for the first 40 days. ' 'Genetic materials outside the uterus have no legal status in Jewish law, for they are not even part of a human being until implanted in a woman's womb'. Most commentators speak of a 'mandate to heal' and a 'mandate to be partners with God in creation,' and some would allow creation of embryos in a petri dish solely for research.

Islamic views generally place ensoulment at the 120th day, after three 40-day periods of development, and hold that a very early embryo has no moral status. According to one interpreter, 'research on stem cells made possible by biotechnical intervention is regarded as an act of faith in the ultimate will of God as the Giver of all life, as long as such an intervention is undertaken with the purpose of improving human health'. ${ }^{10}$

Secular humanist views include those of University of Manchester philosopher John Harris, who warns of the 'trap of potential', meaning that we often regard the embryo in terms of what it might become, under certain circumstances, rather than what it actually is now. Looking at the actual properties of the embryo, in terms too irreverent for most American sensibilities, Harris compares it to many animals that become the Sunday roast. ${ }^{11}$ Yet when it comes to the hundreds of thousands of embryos frozen after IVF, perhaps it is time to look at actuality, rather than potential.

\section{Is compromise possible?}

Compromise between those who hold that deriving stem cells is killing babies and those who hold that benefits to already born persons outweigh the brief existences of early embryos is somewhat analogous to the 'peace process' in the Middle East. Both sides have a passionate sense of right and will adhere to fundamental beliefs. Before Bush, there were several attempts at compromise, the most notable of which was a ruling by the DHHS Legal Department that the government could fund research on stem cells that had already been derived elsewhere, but could not fund the derivation itself. This ruling was an attempt to respect the beliefs of those who thought that derivation was killing human beings, while simultaneously respecting the fervent desires of many patient groups that research proceed. Conservatives regarded this compromise as hypocritical, allowing the private sector to do the dirty work, while the government funded research on an increasing supply of murdered babies. On 9 August, eager to please everybody, especially his conservative supporters, Bush tried another form of compromise, in a well-worded speech that suggested personal agony, as well as political astuteness. Bush reminded listeners, in a reference to use of fetal tissue transplants for Parkinson's disease, that promising scientific endeavors do not always succeed. He ruled that the government could fund research on stem cells that had been derived before, but not after, 9 August provided that they came from embryos left over after fertility treatments (thereby excluding the embryos created specifically for research by the Jones Institute). The compromise was that the government should not encourage destruction of more embryos, but since the damage had already been done in the case of cells derived before 9 August, and the potential to treat disease was real, use of these cells should be funded. Bush's well-worded speech did not please everyone, though most conservatives (with the notable exception of the National Conference of Catholic Bishops) have remained quiet. Many scientific groups, including the American Society of Human Genetics, have offered cautious praise, largely because the statement sets a precedent for federal funding, which they hope may be expanded if preliminary research succeeds. Bush's statement is illogical and without a basis in principled reasoning. There is no reason, beyond the political, why it should be ethical to use stem cells from blastocysts killed before the arbitrary cut-off date of 9 August, but not afterwards.

After Bush's speech, an issue that had previously received little public attention came to the fore: 'therapeutic cloning' (using nuclear transfer to reprogram an adult cell into a blastocyst so that stem cells immunologically compatible with the donor could be derived) may be banned by law Bills in Congress could make not only the procedure illegal, but also any treatments derived from it. Creating blastocysts by parthogenesis is unlikely to solve the embryo debate. Even if the pre-embryo cannot develop into a human being without genetic materials from two parents, conservatives are likely to regard it as human anyway, especially if a 'battle at the border' will help the anti-abortion cause.

In the end, advances (or failures) in science may decide the debate.

\section{Creating embryos for research}

With hundreds of thousands of 'surplus' embryos cryopreserved in US IVF clinics, it appears that there might be no need to create additional embryos solely for purposes of deriving stem cells for basic research. However, it takes far more embryos to produce stem cells than to produce babies. First of all, few parents donate their leftover embryos. For example, the Institute of Reproductive Medicine and Science at St Barnabas Hospital in Livingston, New Jersey, found that of 11402 embryos stored for 1595 patients, only 133 were donated for research (by 22 patients or couples). ${ }^{12}$ Scientists at the Jones Institute, a private infertility clinic in Norfolk, Virginia, thought that only 100 of 10000 frozen embryos might become blastocysts capable of yielding stem cells, partly because frozen embryos from older donors with infertility problems (most couples having IVF) do not develop well. Therefore the Jones Institute commissioned egg and sperm donations from young, healthy donors expressly for research, causing additional political furor in the several weeks before Bush's 9 August speech. Only three of 110 fresh embryos yielded stem cells. ${ }^{12}$ If this trend continues, massive numbers of specially created embryos would be needed. Development of pluripotent stem cells from adult stem cells through nuclear transfer would also require large numbers of eggs. Opposition to egg donation, in which the woman typically receives between $\$ 2000$ and $\$ 4000$ for her time and discomfort, has led some feminists to testify before Congress against therapeutic cloning. These feminists, including some members of the internationally known Boston Women's Health Book Collective, fear that poor women will make 'contracts of desperation' to sell their eggs.

Focus on the fate of the embryo has turned US public attention away from a panoply of ethical issues. These 
include (1) effects on the donors (parents), who may retain an emotional connection, however slight, to the embryo; (2) effects on recipients, especially for brain and neural stem cells (will this alter personhood?); (3) effects on society as people live longer; (4) questions of access and economics; (5) patenting, as research becomes commercialized; (6) unintended effects of stem cell technology on other technologies, such as human reproductive cloning; (7) effects on women who may be egg donors for 'therapeutic cloning'. Access is the overarching ethical issue. The benefits of stem cell research are unlikely to reach most people in developing nations. In the US, the uninsured (about 16-20\% of the US population) would be left out.

The private sector remains unregulated and perhaps should remain so, as long as government remains hamstrung by conservative interests. If stem cell research demonstrates safety and efficacy, public opinion could change rapidly. Political opinion usually follows public opinion.

\section{References}

1 Fletcher JC. Deliberating incrementally on human pluripotential stem cell research. In: Ethical Issues in Human Stem Cell Research, Vol. II. Commissioned Papers. National Bioethics Advisory Commission, US Government Printing Office: Rockville, MD, 2000, pp E1-E50.

2 Eiseman, E. Quick response: use of fetal human tissue in federally funded research. In: Ethical Issues in Human Stem Cell Research, Vol. II. Commissioned Papers. National Bioethics Advis- ory Commission, US Government Printing Office: Rockville, MD, 2000, pp C1-C7.

3 University of Chicago, National Opinion Research Center. National Social Surveys. 2000.

4 Wertz DC, Fletcher JC. Genetics and ethics in global perspective. Unpublished.

5 Williams RM. Major value orientations in America. In: American Society: A Sociological Interpretation, 3rd edn. Knopf: New York, 1970, pp 452-500.

6 Farley MA. Roman Catholic views on research involving human embryonic stem cells. In: Ethical Issues in Human Stem Cell Research. Vol. III. Religious Perspectives. National Bioethics Advisory Commission, US Government Printing Office: Rockville, MD, 2000, pp D1-D5.

7 Axtell J. The School Upon a Hill: Education and Society in Colonial New England. In: New Haven: Yale University Press 1974.

8 Dorff EN. Stem cell research. In: Ethical Issues in Human Stem Cell Research, Vol.III, Religious Perspectives. National Bioethics Advisory Commission, US Government Printing Office: Rockville, MD, 2000, p C4.

9 Zoloth, L.The ethics of the eighth day: Jewish bioethics and genetic medicine. A Jewish contribution to the discourse. In: Ethical Issues in Human Stem Cell Research, Vol. III. Religious Perspectives. National Bioethics Advisory Commission, US Government Printing Office: Rockville, MD, 2000, pp J1-J26.

10 Sachedina A. Islamic perspectives on research with human embryonic stem cells. In: Ethical Issues in Human Stem Cell Research. Vol. III. Religious Perspectives. National Bioethics Advisory Commission, US Government Printing Office: Rockville, MD, 2000, pp G1-G6.

11 Harris J. Wonderwoman and Superman: The Ethics of Human Biotechnology. In: Oxford: Oxford University Press 1992.

12 Stem cell researchers say thousands of frozen embryos are not available. New York Times, 26 August 2001, p 20. 